\title{
PREVALENCE OF PARASITIC INFESTATION IN THE BLUE CRAB PORTUNUS PELAGICUS, DAMIETTA, EGYPT

\author{
By
}

RANIA M. ELBESHKAR ${ }^{1}$, SHEREEN A. FAHMY ${ }^{1 *}$, RABAB M. ALKARADAWE ${ }^{2}$, and SAMYA H. MOHAMMAD

Departments of Zoology, Faculties of Science, Damietta University ${ }^{1}$, El- Arish University ${ }^{2}$ and Port Said University ${ }^{3}$, Egypt ( ${ }^{*}$ Correspondence:

shereenfahmy@du.edu.eg )

\section{Abstract}

The present study focused on parasites that infected the blue crab Portunus pelagicus. This crab is a very popular sea food for the inhabitants of the costal sea of Egypt. Samples were seasonally collected from Mediterranean Sea, Ras El Bar, Damietta, Egypt. The present study exhibited that 2 parasitic species (protozoa and larval nematode) infested the crab. The infestation rate varied according to the infected tissue of the host, seasons and sexes. Gills were found to be higher infected (65\%) than gonads. Seasonal variation in the parasitic infection showed that the highest prevalence was during winter (37\%) and summer (35\%). Sex of the host crab also affected the infestation with the parasites. Male crabs were found to be higher infected (78\%) than females $(22 \%)$. So, the current study provides a contribution to our knowledge of the parasites that infesting one of the most important economic sea foods.

Keywords : Parasites, Protozoa, Larval Nematode, Mediterranean Sea, Blue Crab, Portunus pelagicus.

\section{Introduction}

Decapoda are an order of crustaceans including shrimps, crayfishes, lobsters, and crabs (Hobbs and Lodge, 2010). The crab considered as one of the greatest important nutritious aquatic animals in the world as well as other seafood ( $\mathrm{Ng}$ et al, 2008; Mohammad and Yusuf, 2016). Crab meat is a good source of protein, vitamins and essential minerals (Emmanuel, 2008). Also, crabs contain chromium which acts with insulin in the metabolism of sugar helping the body to maintain normal blood glucose level (Kim, 2014). Hence, crabs are exploited by man and other animals for food (Vogan et al, 2001). Blue swimming crab inhabits Middle Eastern coast of the Mediterranean Sea (Mehanna and El-Aiatt, 2011). Also, it was reported in the Red Sea and Suez Canal (Mehanna, 2005). Portunus pelagicus is one of the most famous blue crab from family Portunidae. It is considered as an important seafood species owing to its potential market value as a soft-shell crab (Hungria et al, 2017; Tavares et al, 2017). Crabs are an intermediate host to numerous parasites (Alsaqabi et al, 2010). It was found that parasitic infestation and its associated diseases are the most important factor threatening fishery industries worldwide (Schmidt et al, 2000). Trichodina and nematodes were isolated from the blue crab Callinectes amnicola (Ekanem et al, 2013). Whilest, Hematodinium perezi was isolated from Callinectes sapidus as stated by Lycett et al. (2018). AlBehbehani (2007) investigated the presence of nematode larvae in blue crab $P$. pelagicus. Parasitic infections of crabs reduce their nutritional value, marketability and abundance. These infections especially high parasitic infections cause loss of color, appearance of dots, making crabs unattractive and may lead to death. Parasitic infection of crabs also causes a reduction in their protein content, destruction of reproductive organs, deformation of nervous system and increased juvenile mortality. Infection of gills reduced the respiration rate (Siddeek et al, 2010).

The present study aimed to: a) identify the parasites that infest the blue crab Portunus pelagicus, b) study the effect of seasonal change and host sex on the prevalence of the parasites.

\section{Materials and Methods}

The present study was carried out in the coastal area of the Mediterranean Sea, Ras 
El Bar, Damietta, Egypt during 2018. Ras El Bar lying in a peninsula on the shore of the Mediterranean Sea. It is surrounded from the western by the Damietta Nile branch. The region of "Lessan" is sited in the extreme northern part of this peninsula. At this point Damietta Nile arm flows in the Mediterranean Sea, which gives Ras El Bar the figure of a triangle (Fig. 1).

Soft tissue was dissected; gills and gonads were perfectly separated. A small piece of tissue was squashed between two glass slides and examined under light microscope (XSZ-107BN) For Parasites Identification.

\section{Results}

The present work revealed that $30 \%$ of $P$. pelagicus was infected with two different parasites (protozoa and nematode larvae). The prevalence of their infection was shown (Fig. 2). The gills and gonads were found infected with the two different parasites. The abundance of parasites in different parts of P. pelagicus was shown (Fig. 3). In gills, protozoa was the dominant (with 26 individuals), followed by nematode larvae (with 9 individuals). On the other hand, gonads infected with 17 individuals of protozoa and 2 individuals of nematode larvae.

Prevalence of the parasites in both gills and gonads was represented (Fig. 4). Gill parasites were the dominant $(65 \%)$, followed by gonad parasites (35\%).

Seasonal prevalence of the two parasites was represented (Fig. 5). Maximum prevalence of protozoa was recorded in summer $(31 \%)$. It was $17 \%$ for nematode larvae in winter. Nematode larvae were declined to reach its minimum one during summer (4\%) and disappeared in spring and autumn. Seasonal variations of the total parasitic infection during the investigated period were represented (Fig. 6). The highest infection was in winter $(37 \%)$, followed by summer $(35 \%)$ and autumn $(17 \%)$, then spring $(11 \%)$. Seasonal prevalence of parasites in each sex of $P$. pelagicus was given (Fig. 7). The highest percentage of parasites in male $(45 \%)$ was recorded in summer, while that of females was detected in spring $(50 \%)$. But, the lowest infection (17\%) was in autumn for both sexes. Each parasite species in both sexes of $P$. pelagicus was shown (Fig. 8). Protozoa infested both sexes $(31 \& 12$ individuals for males \& females respectively).

The nematode larvae were isolated only from male crabs (11 individuals). Generally, the prevalence of parasites in males $(78 \%)$ was higher than in females (22\%).

\section{Discussion}

Portunid or swimming crabs are a commercially important food source in most coastal waters. However, crab considered as an intermediate host to a lot of parasites (Alsaqabi et al, 2010). The present study focused on $P$. pelagicus that considered as one of the most valuable fishery resources. A total of $30 \%$ of crabs were infected with parasites. This was higher than that (12.4\%) was reported by Elumalai et al. (2012). This may be due to the difference in water conditions between the two study areas. However, the present study recorded 2 different parasite species: protozoa and nematode larvae. The infection with nematode larvae was previously recorded in other crabs such as Macrophthalmus hirtipes (Moravec et al, 2003) and Uca uruguayensis \& Chasmagnathus granulatus (Cremonte et al, 2007). Ekanem et al. (2013) reported that the overall prevalence of nematode parasites and other ciliates in blue crab Callinectes amnicola was $12.38 \%$. This percentage was lower than that recorded in the present study $(20.37 \%)$. The difference in parasites prevalence may resulted from the difference in the crab species as well as from the study area. The peak of parasite infection in the present work varied from tissue to another one. It was highly recorded in the gills (65\%) followed by gonads $(35 \%)$. The infestation rate changed also according to the seasons. The highest infection with parasites was observed in winter (37\%) and summer (35\%), while the lowest was in spring (11\%). The highest infection of Callinectes sapidus with parasites was in summer and spring (Lycett 
et al, 2018). Jeffrey and Overstreet (2003) suggested that the distribution of parasites varied from one habitat to another. This variation could be due to host parasite relationship and abiotic factors such as temperature and salinity. Increase temperature causes thermal stress on aquatic animals, so reduced growth, sub-optimal behaviors and caused immunocompetence (Roessig et al, 2004).

In the present study, variation in the infection with parasite may be attributed to the host species. So, the Portunus pelagicus could not withstand the increase in water temperature as well as the decline in it. Alternatively, the crab may be in a bad condition that led to its infection with parasites. Also, Huchin-Mian et al. (2018) found high density infections and increasing host mortality of the infected blue crabs at low temperature. When water temperatures were relatively cooler; this may be the optimal temperatures for parasite proliferation (Messick and Shields, 2000). Also, feeding on crustacea, fish remains and molluscs infected with parasites, may affect the prevalence of parasites in $P$. pelagicus that feeds mainly on them (Lee and Frischer, 2004).

In the current study, the infection in male crabs was higher $(78 \%)$ than females $(22 \%)$. This agreed with Elumalai et al. (2012) who found that infection of male and female $P$. sanquinolentus with parasites was $66.3 \%$ \& $33.7 \%$ respectively. High infection in males is due to being more active than females which tend to be inactive and burrow into soft sediment (Young et al, 2017). So, parasites increase the susceptibility of crabs to diseases, causing nutritive reduction. So, parasites had negative effect on crustaceans, by reducing growth, reproduction, egg survival, longevity, and marketability (Jeffrey and Overstreet, 2003), which are zoonotic parasites (Youssef and Uga, 2014).

\section{Conclusion}

Consumption of not well cooked crabs causes zoonotic infection. Thus, it is one of the mode of transmitting fish protozoa and nematode larvae to man.

\section{References}

Al-Behbehani, BE, 2007: Biological studies on the blue crab Portunus pelagicus and its parasitic infection in Kuwaiti waters. J. Egypt. Soc. Parasitol. 37, 1:215-25.

Alsaqabi, SM, Eshky AA, Albelali A S, 2010: Parasitic Infections in the Blue Crab Swimmer Portunus pelagicus (Linneaus, 1758), (Arthropoda: Crustacea) Found in the Arabian Gulf (Kingdom of Saudi Arabia). Gulf Arab J. Sci. Res. 28, 3:185-96.

Cremonte, F, Etchegoin, J, Diaz, JI, Navone, GT, 2007: Larval spirurida (Nematoda) parasitizing two crab species (Uca uruguayensis and Chasmagnathus granulatus) from the Southwest Atlantic Coast of Argentina. Compar. Parasitol. 74, 1:88-95.

Ekanem, AP, Eyo, VO, Ekpo, IE, Bassey, B O, 2013: Parasites of Blue Crab (Callinectes amnicola) in the Cross River Estuary, Nigeria Intern. J. Fisher. Aquat. Sci. 1, 1:18-21.

Elumalai, V, Selvam, D, Suresh, TV, Pravinkumar, M, Viswanathan, M, et al., 2012: Studies on the Prevalence of Sacculina Spp. Infestation in Portunus Sanguinolentus (Herbst, 1783) from Parangipettai Coastal Waters, Southeast Coast of India. J. Biodivers Endanger species $1: 101$.

Emmanuel, BE, 2008: The Fishery and bionomics of the swimming crab, Callinectes amnicola (DeRocheburne, 1883) from a Tropical Lagoon and its adjacent creek, South West, Nigeria. J. Fish Aquat. Sci. 3, 2:114-25.

Hobbs, HH, Lodge, DM, 2010: Ecology and Classification of North American Freshwater Invertebrates ( $3^{\text {rd }}$ Edition). Science Direct, Academic Press,

Huchin-Mian, JP, Small, HJ, Shields, JD, 2018: The influence of temperature and salinity on mortality of recently recruited blue crabs, Callinectes sapidus, naturally infected with Hematodinium perezi (Dinoflagellata) J. Invertebr. Pathol. 152:8-16.

Hungria, DB, Tavares, CPDS, Pereira, LA, Ostrensky, A, 2017: Global status of production and commercialization of soft-shell crabs. Aquacult. Inter. 25:2213-26.

Kim, S, 2014: Seafood Science Advances in Chemistry, Technology and Applications: Korea: CRC Press.

Lee, FR, Frischer, EM, 2004: The Decline of the Blue Crab: Changing weather patterns and a suffocating parasite may have reduced the num- 
bers of this species along the Eastern seaboard. Amer. Sci. 92, 6:548-53.

Lycett, KA, Chung, JS, Pitula, JS, 2018: The relationship of blue crab (Callinectes sapidus) size class and molt stage to disease acquisition and intensity of Hematodinium perezi infections. PLoS ONE 13, 2:1-14.

Mehanna SF, 2005: Stock Assessment of the blue swimmer crab Portunus pelagicus (Linnaeus 1766) at Bitter Lakes, Suez Canal, Egypt. Egypt. J. Aquat. Biol. Fish. 9, 3:187-213.

Mehanna, SF, El-Aiatt, A, 2011: Fisheries characteristics and population dynamics of the blue swimmer crab Portunus pelagicus (Linnaeus, 1766) from Bardawil lagoon. In: Proc. $4^{\text {th }}$ Intern. Conf. Fisheries and Aquaculture, Cairo, Egypt.

Messick, GA, Shields, JD, 2000: Epizootiology of the parasitic dinoflagellate Hematodinium sp. in the American blue crab Callinectes sapidus. Dis. Aquat. Org. 43:139-52.

Mohammad, SH, Yusuf, MS, 2016: Proximate evaluation of some economical seafood as a human diet and as an alternative prospective valuable of fish meal. J. Fisher. Aqua. Sci. 11:12-7.

Moravec, F, Fredensborg, BL, Latham, AD, Poulin, R, 2003: Larval Spirurida (Nematoda) from the crab Macrophthalmus hirtipes in New Zealand. Folia Parasitol. 50:109-14.

Ng, PKL, Guinot, D, Davie, PJF, 2008: Systema Brachyurorum: Part I: An annotated check list of extant brachyuran crabs of the world. The Raffles Bull. Zool. 17:S1-286.

Roessig JM, Woodley CM, Cech, JJ, Hansen, LJ, 2004): Effects of global climate change on marine and estuarine fishes and fisheries. Rev. Fish. Biol. Fish. 14:251-75.

Schmidt, GD, Roberts, LS, Janovy, J, 2000: Foundations of Parasitology. McGraw-Hill, Boston, USA.

Siddeek, MSM, Zheng, J, Morado, JF, Kruse, GH, Bechtol, WR, 2010: Effect of bitter crab disease on rebuilding in Alaska Tanner crab stocks. ICES J. Mar. Sci. 67:2027-32.

Tavares, CPDS, Silva, UAT, Pereira, LA, Ostrensky, A, 2017: Systems and techniques used in the culture of soft-shell swimming crabs. Rev Aquacult. 1:111-8.

Vogan, CL, Coasts-Ramos, C, Rowley, AF, 2001: A historical study of shell disease syndrome in the edible crab, Cancer pagurus. Dis. Aquat. Org. 47:209-17.

Young, AM, Elliott, JA, Incatasciato, JM, Taylor, ML, 2017: Seasonal catch, size, color, and assessment of trapping variables for the European green crab Carcinus maenas (Linnaeus, 1758) (Brachyura: Portunoidea: Carcinidae), a nonindigenous species in Massachusetts, USA. J. Crust. Biol. 37:556-70.

Youssef, AI, Uga, S, 2014: Review of Parasitic Zoonoses in Egypt. Trop. Med. Hlth. 42, 1:3-14.

Fig. 1: Map showing the study area in the Mediterranean Sea.

Explanation of figures

Fig. 2: Prevalence of different parasites in P. pelagicus.

Fig. 3: Abundance of parasites in gills and gonads of $P$. pelagicus.

Fig. 4: Prevalence of parasites in gills and gonads of $P$. pelagicus.

Fig. 5: Seasonal prevalence of infestation of the parasites in P. pelagicus.

Fig. 6: Seasonal variations of total parasitic infection in $P$. pelagicus during investigated period.

Fig. 7: Seasonal prevalence of parasites in male (left) and female (right) P. pelagicus.

Fig. 8: Abundance of parasites in both sexes of Portunus pelagicus.

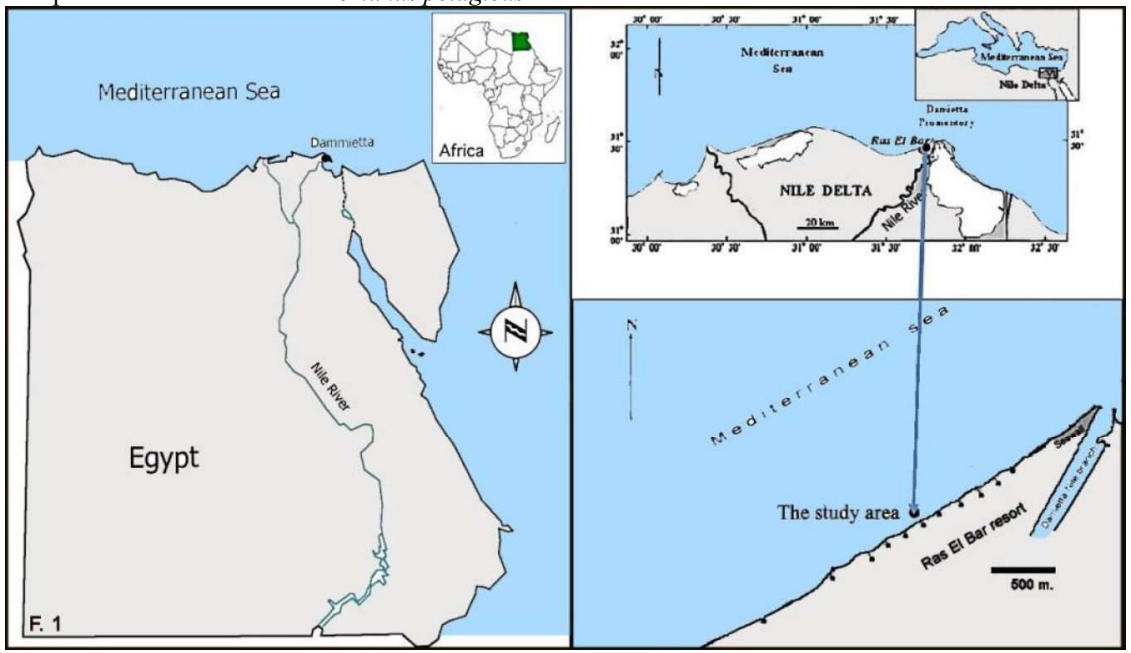



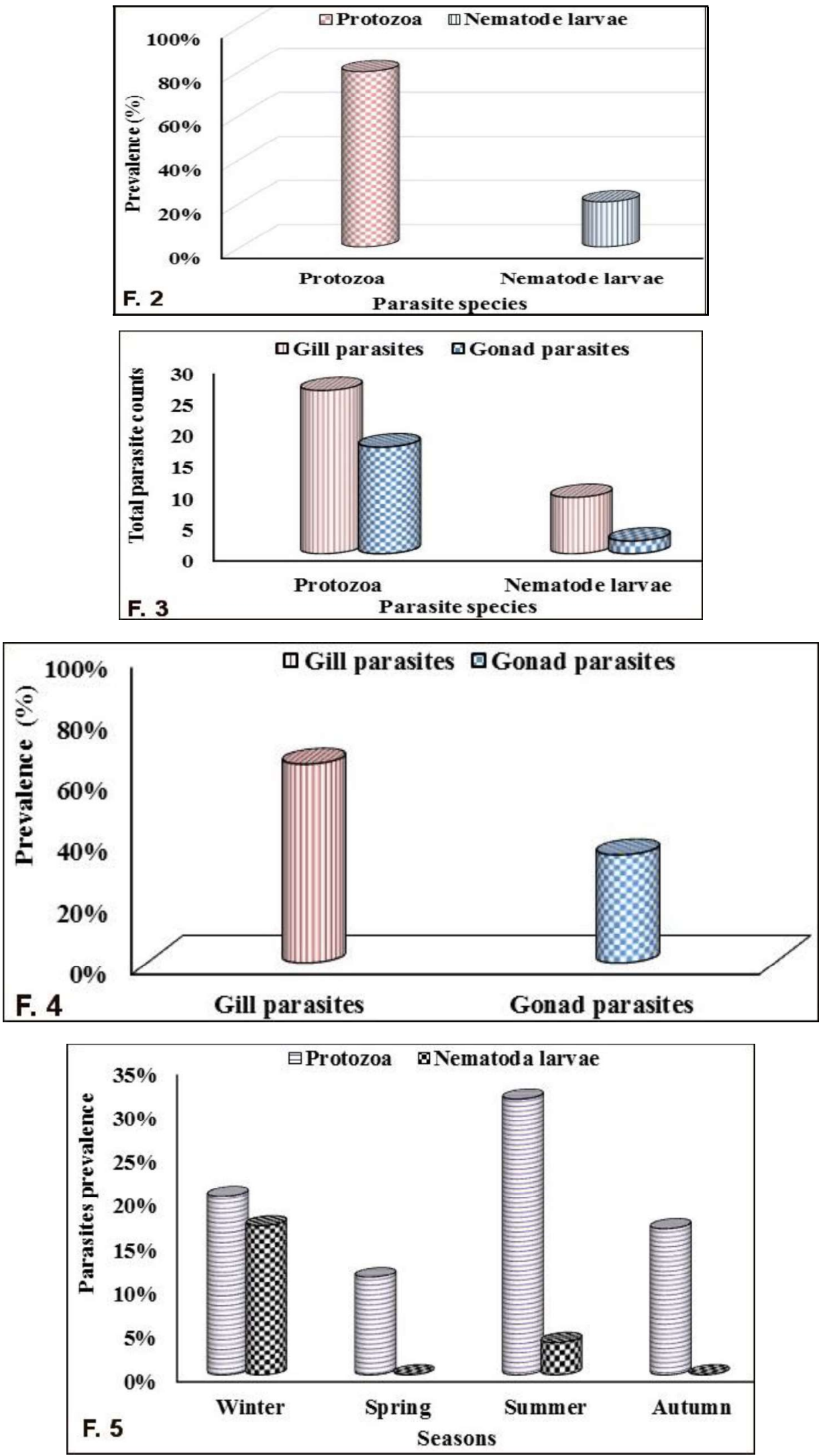

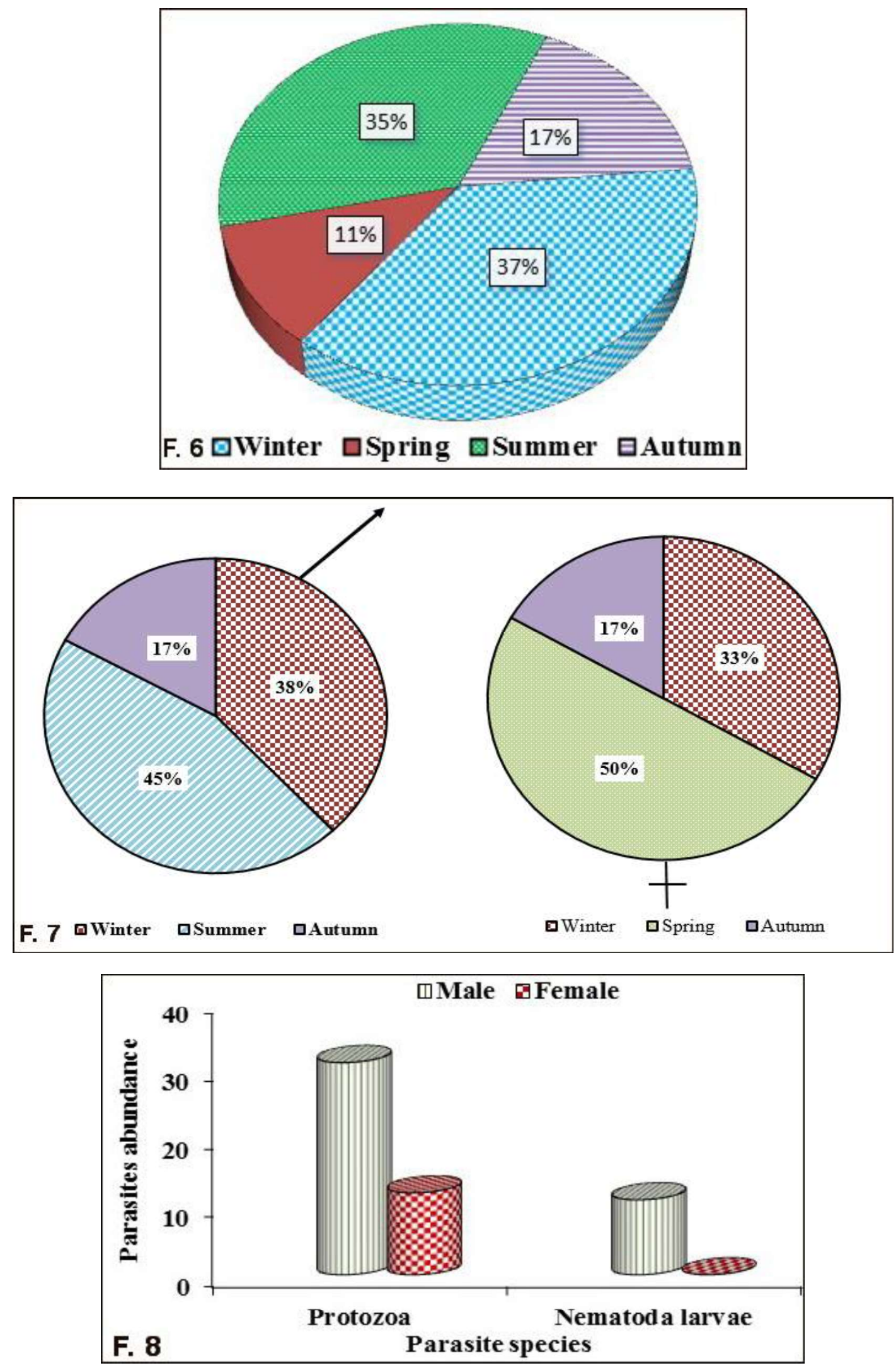